\title{
FOREIGN TERRORIST FIGHTERS AND THE UN \\ INVESTIGATIVE TEAM TO SUPPORT DOMESTIC EFFORTS \\ TO HOLD ISIS ACCOUNTABLE FOR WAR CRIMES, CRIMES \\ AGAINST HUMANITY AND GENOCIDE COMMITTED IN IRAQ: \\ BUILDING A BRIDGE THAT SHOULD BE USED
}

\author{
MONTSERRAT ABAD CASTELOS ${ }^{1}$
}

\begin{abstract}
After examining the United Nations Security Council (UNSC) resolutions referred to the foreign fighters who joined the ranks of ISIS in Iraq and Syria and to the UN Investigative Team to support domestic efforts to hold ISIS accountable for war crimes, crimes against humanity and genocide committed in Iraq (UNITAD or the Investigative Team), this article brings both contents together in order to ascertain whether there may be gaps or problems which should be addressed, since both developments were prompted by the UNSC. It is explored whether there may be certain inconsistencies, such as the one relating to the emphasis placed on different crimes, depending on the resolutions in question. Thus, those related to FTFs focus on terrorism crimes, while those related to UNITAD refer to atrocity crimes. Hereinafter the action and evolution of UNITAD is examined, in order to determine whether it might be helpful to overcome some existing barriers and avoid impunity for atrocity crimes. It will be concluded that UNITAD may provide substantial support, not only in relation to trials in Iraq, but also in third States, by providing useful tools or evidence to prosecute FTFs. Seizing this opportunity will require further action, which will be crucial to promote accountability and justice.
\end{abstract}

Keywords: ISIS; foreign terrorist fighters; UNITAD; atrocity crimes; Iraq; jurisdiction.

Summary: 1. Introduction. 2. Dealing with the VAST numbers of PeOple Who travelled to JOIN ISIS in Iraq (and Syria): The Establishment of the New Legal Category of Foreign Terrorist Fighters and related measures. 3. Facing a bigger Challenge?: The Return of Foreign Terrorist Fighters. 4. First Approach to UNitAd: Its Establishment, Strategic Focus and Early Work. 5. Highlighting some basic Premises And Priorities, But Also Relevant Problems. 5.1. Assumptions, Concerns and Difficulties in a Changing Scenario. 5.2. Gaps, Inconsistencies and Tensions between UNSC Resolutions. 6. SECOND Approach to UNITAD: ItS KeY ROLE TO OVERCOME SERIOUS OBSTACLES IN THE FIELD OF CRIMINAL JUSTICE REGARDING THE FOREIGN TERRORIST FIGHTERS. 6.1. The background regarding Justice: An inextricable Labyrinth. 6.2. UNITAD's work may bring new significant tools to deal with the FTF's prosecution for atrocity crimes beyond terrorist offences. 7. ConCLUSIONS.

\section{INTRODUCTION}

Iraq is the cradle of civilization. Thousands of years ago, it was the scene of prodigious progress for humanity, where writing, city-states and written law flourished. One of the first antecedents in the recognition of human rights was registered there and

\footnotetext{
${ }^{1}$ Professor of Public International Law. Universidad Carlos III de Madrid, Spain (mabad@der-pu.uc3m. es). This article has been written within the framework of the Research Project ODS, Derechos Humanos $y$ Derecho internacional (SDGs, Human Rights and International Law), awarded by the Spanish Ministry for Science, Innovation and Universities (PGC 2018-095805-B-100). All the websites quoted throughout this article were accessed on 21 January 2021.
} 
rights such as religious freedom in the conquered territories were approved under the Empire of Cyrus the Great in the 6th century BC ${ }^{2}$. However, despite this magnificent past, the present has borne witness to paradoxical regressions, more recently in the form of successive waves of violence. Some ensued as a result of external decision-making, such as the illegal invasion of the country in 2003, the consequences of which are intertwined with the very origin of ISIS. However, it is obvious that there are other reasons which help to explain the emergence and, above all, the expansion of this terrorist group. These factors cannot be reduced to just one level, since they are multiple and heterogeneous: thus, on the one hand, the sectarian policies imposed after the occupation which neglected necessary ethnic-religious balances and fed tension and resentment among communities ${ }^{3}$; and, on the other hand, the great socio-economic inequalities and even psychological factors transcending Iraq and the region's scope. One example of the latter is the global resurgence of powerful feelings of identity (Fukuyama, 2018).

As is well known, the self-proclaimed Islamic State (from now on, also the ISIS, ISIL or Daesh, interchangeably) recently held vast areas of Iraq and Syria (more than 100,000 square kilometers) and their 11 million inhabitants under its control. More specifically, since June 2014 when ISIS declared the Caliphate, it has perpetrated not only brutal violations of rights to freedom of worship but also other extremely serious violations of international human rights law (hereinafter IHRL), international humanitarian law (hereinafter IHL) and international criminal law in the territories of both States ${ }^{4}$. The bloody armed conflicts that took place in Iraq and Syria to eradicate ISIS' rule were only recently put to a formal end.

The non-international armed conflict in Iraq took place between June 2014 and December 2017 between ISIS and the Iraqi armed forces (both federal and regional, the latter being the Peshmerga, i.e. the armed forces of the Kurdistan Regional Government). The Iraqi armed forces were supported by parastatal militias and international coalition forces, which intervened at the request of the State in the case of Iraq, in contrast to what has happened in Syria. In fact, there are substantial differences between the Iraqi and Syrian wars, in particular, the nature of the conflict, the contrasting third party intervention, the numbers of victims and the fact that the Syrian armed conflict, especially bloody and complex, still remains open ${ }^{5}$. The Iraqi armed conflict resulted in some 30,000 civilian deaths

\footnotetext{
${ }^{2}$ In point of fact, the Cyrus Cylinder, the piece of clay where those rights were engraved, was discovered in the ruins of Babylon, in Mesopotamia, present-day Iraq; see The British Museum, 'The Cyrus Cylinder'. Available at https://www.britishmuseum.org/research/collection_online/collection_object_details

${ }^{3}$ See Smith (2014).

${ }^{4}$ For the facts regarding the rise and decline of IS, see R. Callimachi, 'Fight to Retake Last ISIS Territory Begins', The New York Times, 11 September 2018. Available at https:/www.nytimes.com/2018/09/11/world/ middleeast/isis-syria.html and also BBC News, 'Islamic State and the crisis in Iraq and Syria in maps', 28 March 2018. Available at https:/www.bbc.co.uk/news/world-middle-east-27838034.

5 The Syrian Democratic Forces (Arab-Kurdish militias), backed by the United States-led International Coalition, also announced victory over Daesh in Syria though; J. Stocker, 'SDF declares 'total' victory over ISIS in Syria', The Defense Post, March 23, 2019. Available at https://thedefensepost.com/2019/03/23/sdfvictory-isis-syria/
} 
in Iraq and almost double that figure in injuries, according to the most reliable estimates (Report by the Special Rapporteur on extrajudicial, summary or arbitrary executions on her mission to Iraq, 2018, para. 1) $)^{6}$. Although the numbers of deaths and displaced persons in Iraq have been considerably lower than those reported in Syria, the crimes committed by ISIS reflect the same pattern of outrage. The liberation of large areas of Iraq, which the ISIS had kept under its control (Mosul was recovered in July 2017 and the declaration of victory over the IS was made by the Iraqi Prime Minister in December $2017^{7}$ ), brought to light the tremendous magnitude of the crimes committed against the inhabitants of those territories (UNAMI/OHCHR, Report on the Protection of Civilians in the context of the Ninewa Operations and the retaking of Mosul City, 2017). There were not only the testimonies of survivors and witnesses, but also material and human vestiges of horrendous crimes, which are still being uncovered to this day. Indeed, Daesh committed atrocity crimes throughout this Iraqi war, i.e. war crimes, crimes against humanity and genocide against members of different religious minorities.

As the Special Adviser and Head of the United Nations Investigative Team to Promote Accountability for Crimes Committed by ISIS in Iraq transmitted within their first report to the United Nations Security Council (UNSC) in 2018, more than 200 mass graves containing the remains of thousands of men, women and children were discovered in areas previously controlled by the Islamic State: 'These large-scale crime scenes are sites of harrowing human loss, profound suffering and shocking cruelty' (First report UNITAD, November, 2018, para. 9). According to the first estimates made in 2017 by professionals from the Iraqi Medical-Legal Institute, it was calculated that the processes of discovery of mass graves, exhumation and identification could take more than 800 years, at the then working rate ${ }^{8}$. Further mass graves have subsequently been discovered, and the UN Assistance Mission for Iraq (UNAMI) and the Office of the UN High Commissioner for Human Rights (OHCHR), among other entities, assumed that they will continue to discover more in the coming months, and even years (UNAMI/OHCHR, November 2018, 'Unearthing Atrocities: Mass Graves in territory formerly controlled by ISIL', para. 9).

It is incontestable that all serious violations committed during the conflict should be brought to justice, regardless of the affiliation of the alleged perpetrators, since other parties to the conflict also committed serious breaches of IHL and IHRL. However, it seems that Iraq has major problems in laying proper foundations for transitional justice and ensuring

\footnotetext{
${ }^{6}$ Despite the formal declaration of victory in Iraq and the end of most of the hostilities between ISIS and the Iraqi forces, it should be noted that, in reality, the armed conflict has not yet totally come to an end and there is a high risk of a resurgence. See, in this regard, J. Matar, The War Report. Iraq: Any hope for Change?, The Geneva Academy (November 2019), at 2. Available at https://www.geneva-academy.ch/joomlatools-files/ docman-files/Iraq\%20Any\%20Hope $\% 20$ for $\% 20$ Change.pdf

${ }^{7}$ Declaration made on December 9, 2017; see M. Chmaytelli, 'Iraq declares final victory over Islamic State', Reuters, 9 December 2017. Available at https://www.reuters.com/article/us-mideast-crisis-iraq-islamicstate/ iraq-declares-final-victory-over-islamic-state-idUSKBN1E30B9; and M. Coker and F. Hassan, 'Iraq Prime Minister Declares Victory Over ISIS', The New York Times, 9 December 2017. Available at https://www. nytimes.com/2017/12/09/world/middleeast/iraq-isis-haider-al-abadi.html.

${ }^{8}$ See Report by Special Rapporteur on extrajudicial, summary or arbitrary executions (2017).
} 
future stability. Furthermore, the country has been experiencing mass protests since October 2019, against corruption and the government's sectarian quota-based system, among other motives. UNAMI has reported that Iraqi authorities have committed serious human rights violations and abuses, including the deliberate killing of unarmed protesters, arbitrary detention and ill-treatment of torture. Besides, the Special Rapporteur on the human rights of internally displaced persons on her visit to Iraq in 2020, reported that remaining displaced population continues to require humanitarian assistance and "conditions in places of return and the durable solutions available to internally displaced persons remain of paramount concern" (Report of the Special Rapporteur on the human rights of internally displaced persons, 2020, par. 70). At the same time, more than 10,000 ISIS fighters are estimated to remain active in Iraq and Syria in 2020. This is happening against a background of the Covid-19 disease, in which there is surge in ISIS activity (and among some of its regional affiliates) particularly in Iraq $^{9}$ and Syria (Eleventh report of the Secretary-General on the threat posed by ISIL to international peace and security, 2020, paras. 3 and 13).

In view of the above, the starting points of this article are, on the one hand, the analysis of the phenomenon of FTFs and, on the other hand, the examination of the UN Investigative Team to support domestic efforts to hold ISIS accountable for war crimes, crimes against humanity and genocide committed in Iraq. The following purpose will be to bring both parameters (FTFs and the Investigative Team) together, in order, in the first place, to explore if there are inconsistencies, gaps or problems between them, in particular, between the UNSC resolutions that prompted both developments; and, in the second place, to determine if the Team's action and evolution could be crucial in solving problems and overcoming existing barriers. Therefore, the structure of this article is straightforward and it will address the following aspects. First, the resolutions adopted by the UNSC with respect to FTFs and, second, the aforementioned Iraqi Investigative Team will be examined, looking for possible lessons learnt from its general aspects, in a first round. Third, possible tensions, gaps and incongruities between the UNSC's resolutions shall be searched. Fourth, UNITAD will be approached in a second round, after looking at the labyrinth of criminal justice in the current context, for the purpose of determining whether the Investigative Team might provide a substantial support for future prosecutions, in Iraq and beyond. Lastly, all these issues will be weighted in order to ascertain possible repercussions and draw conclusions.

\section{Dealing with the Vast Numbers of People Who Travelled to Join is in Iraq (And Syria): The Establishment of the New Legal Category of Foreign TERrorist Fighters and Related Measures}

Given that the term and concept of foreign fighters and their presence in the reality of numerous conflicts are nothing new (Malet, 2018) ${ }^{10}$, the flow of people traveling mainly to Syria and Iraq in recent years to join the ranks of ISIS was logically perceived as an

\footnotetext{
${ }^{9}$ After a period of relative calm, terrorist attacks took place in Baghdad on 21 January 2021, carried out by two suicide bombers, killing at least 32 people and injuring more than 100.

${ }^{10}$ This author takes the Vienna Congress as the main point of departure. For the 'my enemy's enemy is my friend' dynamics in relation to specific conflicts (like Afghanistan) which served as 'incubators' of some problems we are facing today. See also Gilles de Kerchove (2016).
} 
unprecedented threat. There were other contributing factors, such as the sheer volume of displacements and the fact that the main recipient of these accessions of fighters was not a normal contending party in conflict but a heinous actor like ISIS (Marrero Rocha, 2019). When the Caliphate was declared in June 2014, ISIS had around 40,000 foreigners from more than 110 countries fighting in its ranks (Soufan Group, 2104-2017). These figures, together with its vast territorial expansion (unprecedented in the case of a terrorist group) and the parastatal structure from which it exercised a terrifying control over the population, raised the alarm. The UNSC reacted by creating the category of foreign terrorist fighters based on Resolutions $2170^{11}$ and $2178^{12}$, both adopted in 2014, and based on the previous $1373^{13}$, making use of Chapter VII of the UN Charter. Through Resolution 2178, the UNSC lowered the punitive line by forcing States to criminalize conducts that in most cases were still not constitutive of a crime in their domestic legal systems, as long as mere intention was involved ${ }^{14}$.

Obviously, a reaction was necessary to interrupt the flow of individuals traveling to Iraq and Syria. However, it seems clear that the UNSC should have avoided creating the category of 'foreign terrorist fighters', which not only lacked foundation in IHL, but also generated great confusion around its content, due to the merging involved of two divergent concepts. The message from the main promoter and guardian of IHL, the International Committee of the Red Cross (ICRC), was unequivocal in this regard, recalling that even the concept of 'foreign fighter' does not exist as such in IHL, and therefore 'the applicability of IHL to a situation of violence in which such fighters may be engaged depends on the facts on the ground and on the fulfillment of certain legal conditions stemming from the relevant norms of IHL' (32nd International Conference of the Red Cross and Red Crescent, December 2015, p. 19). To be considered a combatant, it is necessary to be linked to an armed conflict. However, it must also be borne in mind that the status of prisoner of war does not exist within non-international armed conflicts. Furthermore, it is necessary to take into account that the 2014-2017 Iraqi war was a conflict of this latter nature, i.e. noninternational, and the status of prisoner of war could not exist within this conflict between the abovementioned forces and Daesh, not even in the case of capture (ibid, pp. 24-25.) ${ }^{15}$. Hence, if the status of FTFs was not so relevant from that legal point of view, there is another reason why the creation of the category of foreign terrorist fighters is itself subject to criticism. The description of the behaviors that States would be forced to criminalize in their domestic laws according to UNSC Res 2178 should have been sufficient.

\footnotetext{
${ }^{11}$ UN Doc. S/RES/2170 (2014). See preambular par. 12 and pars. 7-10.

${ }^{12}$ UN Doc. S/RES/2178 (2014).

${ }^{13}$ UN Doc. S/RES/1373 (2001).

${ }^{14}$ See the main conducts typified in para. 4, a) b) and c).

${ }^{15}$ However, as regards the course of the conflict, it should be added that although foreign terrorist fighters do not have the guarantees provided in Protocol II (it is not even appropriate to assess whether the requirements for its application are met, as Iraq is not one of its 168 States Parties; see 'Treaties, States Parties and Commentaries'. Available at https://ihl-databases.icrc.org/applic/ihl/ihl.nsf/States.xsp?xp_ viewStates=XPages_NORMStatesParties\&xp_treatySelected=475), they would always have (at least from legal theory) the guarantees provided according to common Article 3 and the safeguards stemmed from customary law (ICRC, ibid., p. 25).
} 
Resolution 2178 has been extensively analyzed by experts, who have highlighted, among other Achilles' heels, the uncertainties raised by the objectification of criminal liability that Resolution 2178 brings with it, as it is built on a reality (terrorism) that lacks a normative concept at the universal level (Ambos, 2014), in wake of the extended deadlock of the Draft comprehensive convention against international terrorism. Furthermore, another criticism of Resolution 2178 is the shift of the punitive barrier, the focus of which is also on the intention to commit certain acts. This move poses specific and diverse problems, such as difficulties to obtain evidence regarding only purposes or intentions (Marrero Rocha, 2019, p. 46) or the risk of a possible abusive use by oppressive regimes to persecute political opponents or even to stigmatize certain social groups (Segura Serrano, 2019, p. 151). This text will not examine issues previously dissected by specialists, but only the confrontation of certain contents of Resolution 2178 with other UNSC resolutions that concern FTFs, in order to subsequently determine if UNSC strategy is adequate to deal with the persecution of FTF's for their involvement in war crimes, crimes against humanity and genocide perpetrated in Iraq.

Following Resolution 2178, the UNSC Counter-Terrorism Committee identified a series of Guiding Principles on FTFs at a special meeting held in Madrid, in July 2015, which were subsequently adopted by the Security Council in December 2015 (Madrid Guiding Principles $)^{16}$. These 35 guiding principles represent a soft law tool to assist Member States in ensuring compliance with Resolution 2178 and stopping the flow of FTFs. The application of measures based on this UNSC Resolution and these principles, together with military action against Daesh in Iraq and Syria, can be considered conditioning factors for the interruption of the flow of FTFs to these countries (Analytical Support and Sanctions Monitoring Team concerning ISIS, Al-Qaida and associated individuals and entities, 2017 and 2018).

Due to the fact that the Madrid guiding principles are aimed at ensuring the implementation of Resolution 2178, they contemplate mostly aspects related to the prosecution of FTFs, purposely covering the new typified behaviors, that is, those related with acts of terrorism. Thus, although, the Madrid Guiding principles explicitly cover crimes against humanity, war crimes and genocide through its principle number 32 (according to which, "Member States should ensure that their criminal justice systems are capable of dealing with all serious crimes committed by foreign terrorist fighters, in particular war crimes, crimes against humanity and crimes related to gender"), do not include further specific measures concerning atrocity crimes.

\section{Facing a Bigger Challenge?: The Return of Ftfs}

The new legal category of FTFs brought by the UNSC Resolution 2178, whatever its shortcomings may be, is here to stay. It was rapidly consolidated in the field of legal obligations through another subsequent UNSC action: Resolution 2396, adopted on December 21, 2017, which seeks to address the threat of the return of $\mathrm{FTFs}^{17}$. Acting

\footnotetext{
${ }^{16}$ UN Special Rapporteur on Extrajudicial, Summary or Arbitrary Executions (2017).

${ }^{17}$ UN Doc. S/RES/2396 (2017).
} 
again under Chapter VII of the United Nations Charter, the UNSC begins on this occasion from the serious and growing threat posed by foreign terrorist fighters who return to their countries of origin or nationality or move to third countries, particularly from conflict zones. In addition, the threat exists of adhesion of FTFs to entities such as ISIS, the AlNusra Front and other cells, affiliated entities or groups splintered or derived from ISIL, Al-Qaida or other terrorist groups that could be trying to return to their countries of origin or nationality or to move to third countries ${ }^{18}$. To tackle the return of FTFs, the Resolution obliges states to adopt a series of measures (some of which had already been adopted by the US and the EU), in particular, those related to border security and information sharing ${ }^{19}$. However, it also includes judicial and international cooperation measures ${ }^{20}$ as well as new prosecution, rehabilitation and reintegration strategies ${ }^{21}$.

Resolution 2396 reinforces 2178, and at the same time leaves little room for interpretation that it is aimed at detecting those FTFs (i.e. nationals for the main States concerned) who are returning or want to return. It also prepares measures to confront the threat that these individuals pose. However, its aim is not to provide means for nationals to return to their respective countries and face the consequences of their crimes. Although prosecution is one of those measures foreseen, it is essentially designed within its connection with the behaviors previously criminalized by UNSC 2178, as well as with participation or support given to the financing, planning, preparation or commission of terrorist acts ${ }^{22}$. The emphasis is placed principally on the prevention of future terrorist acts $^{23}$. As a result of that, Resolution 2396 does not explore certain issues and, instead, overemphasizes others. Thus, the UNSC 'reaffirms' that 'those responsible for committing or otherwise responsible for terrorist acts, and violations of international humanitarian law or violations or abuses of human rights in this context, must be held accountable ${ }^{24}$. Why is the wording 'in this context' used? Perchance, the potential scope of the prosecutions is constrained thereby? Should it be interpreted as focusing on the prosecution of acts that constitute a violation of IHL or IHRL only when there are terrorist acts involved? Obviously, this should not be so. Nonetheless, an autonomous mention of war crimes, crimes against humanity and genocide is lacking

Certainly, an unwelcome consequence of the intense focus on terrorism in Resolution 2396 was the eclipsing of atrocity crimes. A clearer reference to these international crimes would have been especially logical and necessary in a Resolution such as this one, which refers to returnees from conflict zones where such crimes have been committed and FTFs may presumably have participated in their commission. Nonetheless, there is obviously nothing to prevent an interpretation that considers them to be included. In fact, it should be construed as such, since this conclusion seems to be the most logical one derived from

\footnotetext{
${ }^{18}$ Preambular pars. 10 and 15.

${ }^{19}$ Pars. 2-16.

${ }^{20}$ Pars. 17-28.

${ }^{21}$ Pars. 29-41.

${ }^{22}$ Para. 17.

${ }^{23}$ See, for instance, as OSCE and UNOCT are discussing "ways to responsibly use passenger data to prevent return of foreign terrorist fighters"'(2020).

${ }^{24}$ Para. 19.
} 
all the elements involved. Thus, in another paragraph of the same Resolution, the UNSC refers to the possible crimes in a generic sense ${ }^{25}$.

Also, there are other gaps. One that should be highlighted is that no other potential crimes are mentioned in Resolution 2396 either. Another more glaring gap appears when this same Resolution later refers to 'extradition' (mentioned four times, twice in the Preamble and twice more in the Resolution's operational part ${ }^{26}$ ), but only in connection with terrorism-related causes.

Resolution 2396 also contains a mandate for the Counter-Terrorism Committee to review the 2015 Madrid Guiding Principles: 'in light of the evolving threat of foreign terrorist fighters, particularly returnees, relocators and their families, and other principal gaps that may hinder States'abilities to appropriately detect, interdict, and where possible, prosecute, rehabilitate and reintegrate foreign terrorist fighter returnees and relocators and their families (...) ${ }^{27}$. To fulfill this mandate, the Committee reaffirmed the relevance of the Madrid Guiding Principles and approved an Addendum (at the special meeting held in New York, on December 13, 2018) whose additional guidelines contain 17 new guiding principles ${ }^{28}$. In this Addition, new guiding principles regarding prosecution are contemplated. It should be noted that these also continue to place the primary focus on acts related to terrorism, despite the fact that among the returnees there will presumably be perpetrators of atrocity crimes. Specifically, the new guiding principle 46 states that:

'In undertaking efforts to develop and implement prosecution, rehabilitation and reintegration strategies and protocols, Member States should: (...) Implement their obligations to ensure that terrorists are brought to justice, as required under resolutions 1373 (2001), 2178 (2014) and 2396 (2017), and ensure that their criminal justice systems are capable of dealing with all serious crimes that may have been committed by foreign terrorist fighters' ${ }^{29}$.

Although this previously quoted statement refers to 'all serious crimes', it should be noted that the Resolution only indicates terrorist crimes as a parameter, and that crimes that could potentially go beyond that field are not explicitly mentioned here either. A single generic reference to IHL violations and human rights violations or abuses is contained (similarly to aforementioned items, when referring to the Resolution 2396), but once more using the wording 'in this context', which could thus be understood as being linked with acts of terrorism. Therefore, although measures related to prosecution are foreseen, there are no

\footnotetext{
${ }^{25}$ In particular, the UNSC: 'calls upon Member States, including through relevant Central Authorities, as well as UNODC and other relevant UN entities that support capacity building, to share best practices and technical expertise, informally and formally, with a view to improving the collection, handling, preservation and sharing of relevant information and evidence, in accordance with domestic law and the obligations Member States have undertaken under international law, including information obtained from the internet, or in conflict zones, in order to ensure foreign terrorist fighters who have committed crimes, including those returning and relocating to and from the conflict zone, may be prosecuted'; ibid, para. 20 .

${ }^{26}$ Para. 24.

${ }^{27}$ Para. 44.

${ }^{28}$ UN Doc. S/2018/1177.

${ }^{29}$ Subsection a).
} 
explicit references to atrocity crimes, not even on the occasions when the word 'impunity' is used (twice) $)^{30}$. Once more, when reference is made to the need for States to 'fully comply' with their 'obligations' relating to the extradition and prosecution 'of terrorists', there is not one single generic mention of atrocity crimes, but instead the explicit reference is reduced to 'their obligations under international counter-terrorism conventions to which they are parties ${ }^{31}$.

\section{First Approach to Unitad: Its Establishment, Strategic Focus and EARLY WORK}

Iraq's final military victories, in December 2017, 'raised an unprecedented challenge in transitional justice: how to prosecute thousands of suspected ISIL members, including foreign fighters, held in Iraqi custody' (Gilmore, 2018, p. 960). Despite having mediated previous demands from different sources for the adoption of some type of action against IS atrocities (particularly since the Sinjar massacre), the UNSC did not prepare a draft Resolution until the formal request was made by the Iraqi Government. However, the pressure from a diverse range of entities also played a crucial role, as did the campaign implemented by Amal Clooney and Nadia Murad, which garnered such widespread media attention that their activism was in fact considered to have been one of the triggers for ${\text { UNSC } \text { action }^{32} \text {, alongside UK action }}^{33}$.

On August 9, 2017, the Iraqi Minister of Foreign Affairs sent a letter to the United Nations Secretary General (UNSG) for transmission to the UNSC, requesting the assistance of the international community to ensure that members of ISIS be held accountable for crimes committed in Iraq, in particular those that could constitute 'crimes against humanity' ${ }^{34}$. From the beginning it was clear that an identifying element of this envisaged mechanism would be its dependence on Iraqi consent ${ }^{35}$. The Resolution gave Iraq 'something approaching a veto' regarding the scope of work to be subsequently carried out by the Investigative Team (Van Schaack, 2018, ‘The Iraq Investigative Team”, p. 115).

A month later, the UNSC unanimously adopted Resolution 2379, without invoking Chapter VII of the UN Charter. In this Resolution, the UNSC reiterates "its condemnation

\footnotetext{
${ }^{30}$ See paras. 9 and 35 .

${ }^{31}$ Para. 40.

${ }^{32}$ See A. Clooney, 'Finally, We Have A Coordinated Effort To Bring ISIS To Justice', The Huffpost, September 22, 2017. Available at https:/www.huffingtonpost.com/entry/amal-clooney-isis_us_59c569bae 4b01cc57ff22947?guccounter=1; H. Saul, 'Amal Clooney delivers damning speech to the UN over failure to stop ISIS 'genocide'": 'I am ashamed", The Independent, September 17, 2016. Available at https://www .independent.co.uk/news/people/amal-clooney-delivers-damning-speech-to-the-un-over-isis-genocide -i-wish-i-could-say-im-proud-to-be-a7313551.html; Nadia's Initiative, 'Why yesterday's UN Security Resolution was a landmark decision for the Yazidis', September 24, 2017. Available at https://nadiasinitiative. org/news/2017/9/24/why-yesterdays-un-security-resolution-was-a-landmark-decision-for-the-yazidis.

${ }^{33}$ The UK took over the writing of the draft. In this regard, it can be interpreted that this shift in the British position (from emphasizing reconciliation to promoting responsibility) could represent an effort to show 'an internationally-engaged post-Brexit Britain' (Van Schaack, 2018, 'The Iraq Investigative Team, p. 115). ${ }^{34}$ UN Doc. S/2017/710.

${ }^{35}$ It is also reflected in the role of the Investigative Team, which will refer primarily to the Iraqi courts, as shown in different revealing passages of the Resolution 2379, and additionally in the terms of reference developed later.
} 
of all violations of international humanitarian law, violations and abuses of international human rights law, and acts of terrorism, and expresses its determination that, having united to defeat the terrorist group ISIL (Da'esh), those responsible in this group for such acts, including those that may amount to war crimes, crimes against humanity, and genocide, must be held accountable" 36 and requests that the UNSG establish the Investigative Team, based on the recognition that the acts committed by Daesh 'may amount to war crimes, crimes against humanity or genocide', and that their perpetration 'is part of the ideology and strategic objectives of ISIL (Da'esh), and used by ISIL (Da'esh) as a tactic of terrorism ${ }^{37}$. The UNSC anticipates that the Team will be placed under the leadership of a Special Adviser 'to support domestic efforts to hold ISIL (Da'esh) accountable by collecting, preserving and storing evidence in Iraq of acts that may amount' to crimes of such a nature ${ }^{38}$. It also foresees the development of specific regulations (through the subsequent elaboration of the Terms of Reference) 'to ensure the broadest possible use before national courts, and complementing investigations being carried out by the Iraqi authorities, or investigations carried out by authorities in third countries at their request ${ }^{39}$. Although an initial period of 60 days was accorded for the elaboration of such 'terms of reference', several extensions were necessary due to the controversy generated by the issue of the death penalty, in force in Iraq ${ }^{40}$, although suspended by a moratorium in Kurdistan (Report by the Special Rapporteur on extrajudicial, summary or arbitrary executions on her mission to Iraq, 2018) ${ }^{41}$. Thereafter, the terms of reference highlight, when dealing with the use and sharing of evidence, 'the importance of assisting Iraq and other States in holding ISIL (Da'esh) members accountable, in particular those who bear the greatest responsibility, including in terms ofleadership, which can include regional or mid-level commanders, in order to assist in countering terrorism, including by stemming financing the continued flow of international recruits to ISIL (Da'esh) ${ }^{342}$. Subsequently, the first report of the Investigative Team, in addition to recognizing 'the global impact and reach of ISIL terrorist activities, as well as its extensive recruitment of foreign terrorist fighters ${ }^{24}$, seems to highlight two other elements in connection with this same object: first, the emphasis placed by the international community on 'the crucial importance of holding senior members accountable for the crimes they have committed, on the basis of objective, evidence-based investigation and analysis ${ }^{244}$ and second, the aim, among its guiding principles, of 'focusing on those who bear the greatest responsibility' ${ }^{45}$, in coherence with the Terms of Reference ${ }^{46}$.

\footnotetext{
${ }^{36}$ Para 1.

${ }^{37}$ Para. 2 (operational and also preambular para. 5).

${ }^{38}$ Para. 2.

${ }^{39}$ Ibid.

${ }^{40}$ See UNAMI/OHCH (2014); UN Doc. A/HRC/38/44/Add.1 (2018), p. 6.

${ }^{41}$ See also UN Doc. A/HRC/38/44/Add.1 (2018), p. 6.

${ }^{42}$ Para. 29. See also See Van Schaack (2018, Just Security).

${ }^{43}$ UNITAD First report (2018), para. 16.

${ }^{44}$ Ibid., para. 10.

45 'Principle 4: The Investigative Team will focus its initial investigative efforts on those most responsible for the atrocities committed by ISIL, including through the ordering of such acts. This will necessitate an emphasis on senior ISIL leadership, as well as regional or mid-level commanders'; ibid., para. 26.

46 Terms of Reference of the Investigative Team to Support Domestic Efforts to Hold ISIL (Da'esh) Accountable of Acts that May Amount to War Crimes, Crimes against Humanity and Genocide Committed in Iraq, established pursuant to Security Council resolution 2379 (2018), para. 29.
} 
UNITAD (the Investigative Team or IT) can be counted among the recently established mechanisms at UN level to promote responsibility for serious violations of human rights and IHL, including those related to Syria (on the one hand, the Commission of Inquiry on Syria, created by the Human Rights Council to investigate human rights violations perpetrated there $^{47}$, and, on the other hand, the International, Impartial and Independent Mechanism to Assist in the Investigation and Prosecution of Those Responsible for the Most Serious Crimes under International Law Committed in the Syrian Arab Republic since March 2011, created by the UNGA in December $2016^{48}$ ); or the Commissions of Inquiry created by the Human Rights Council for Burundi, in 201549, for Yemen, in 2017 ${ }^{50}$, or for Myanmar, in $2018^{51}$. These UN investigative bodies, although clearly different, could be seen as an alternative to Security Council referrals to the International Criminal Court under Article 13 of the Rome Statute or the establishment of ad hoc international or hybrid tribunals (Gilmore, 2018, p. 960.). In any event, among of all the investigative bodies mentioned, only the one related to Iraq has been established by a Security Council Resolution, with all that this entails, in particular the consensus and the power which are behind.

After the initial design of its framework of action ${ }^{52}$, UNITAD became operational in the field in $2019^{53}$, having different premises and facilities in Iraq ${ }^{54}$. It is currently composed of 155 personnel, including 134 staff members $^{55}$, ensuring on the one hand, gender and geographical balance and, on the other hand, the Iraqi component of the Investigative Team, also reflecting the diversity of communities throughout Iraq ${ }^{56}$. The Investigative Team adopted an initial implementation plan envisaging the following three initial areas for investigation of crimes committed by ISIS: 1) Attacks committed against the Yazidi community in Sinjar in August 2014; 2) Crimes committed in Mosul between 2014 and 2016, including the execution of religious minorities, crimes involving sexual and gender-based violence and crimes against children; 3) The mass killing of unarmed Iraqi air force cadets from Tikrit Air Academy in June 2014 (UNITAD, Second Report, May 2019, para. 13). However, subsequently two additional field investigations units were established to investigate into crimes committed against Christian, Kakai, Shabak, Sunni and Turkmen Shia communities in Iraq, in line with the strategic objective of the Investigative Team to ensure its ability to investigate acts committed against all affected communities in the country (UNITAD Fourth report, May 2020, paras. 7-17). Certainly, although the main driving forces behind resolution 2379, when creating the Investigative Team for Iraq, were connected with the persecution of the Yazidi genocide, the UNSC made it clear from the beginning that the one of the main goals of the Special Adviser to the Investigative Team should be to promote throughout the world accountability for acts

\footnotetext{
${ }^{47}$ Human Rights Council, UN Doc. A/HRC/S-171 (2011).

${ }^{48}$ UN Doc. A/RES/71/248.

${ }^{49} \mathrm{UN}$ Doc. A/HRC/S-24.

${ }^{50}$ UN Doc. A/HRC/36/31.

${ }^{51}$ UN Doc. A/HRC/39/L.22.

${ }^{52}$ See UNITAD First report (November 2018),

${ }^{53}$ See UNITAD Second report (May 2019).

${ }^{54}$ See UNITAD Fourth report (May 2020), paras. 22-23.

${ }^{55}$ See UNITAD Fifth report (November 2020), para 39.

${ }^{56}$ See UNITAD Fourth report, paras. 18-21.
} 
that may amount to war crimes, crimes against humanity or genocide committed by ISIS, and work with survivors ${ }^{57}$. In coherence with this, the Investigative Team has also been highlighting and seeking to implement this aim ${ }^{58}$.

Excavations at mass graves and collection of forensic testing have always been a priority for the Investigative Team, along with the collection and storage of documentary and digital evidence, on the one hand, and the collection of testimonial evidence and protection of witnesses, on the other hand. Furthermore, some key requirements were identified from the beginning, in order to focus the Team's analytical capacity, in particular: on senior and provincial leadership structures, media apparatus, foreign terrorist fighters recruitment processes and mapping the whereabouts of Daesh members ${ }^{59}$. Besides, a statistical analysis system has been developed in order to cover 'data pertaining to all information requirements, including ongoing ISIL activities, arrests, trial and the sentencing of ISIL members by Iraqi courts, as well as other incidents of relevance ${ }^{\prime 60}$.

\section{Highlighting Some Basic Premises and Priorities, But also Relevant Problems}

\subsection{Assumptions, Concerns and Difficulties in a Changing Scenario}

The return of jihadists has been disruptive and slower than expected (UN Analytical Support and Sanctions Monitoring Team, 2018, para. 6).The existence of a 'devolved threat' with regard to ISIS plans in order to establish itself wherever possible, 'with such returnees and relocators planning to bed down wherever possible' was assumed from the beginning (ibid.). Beyond the cases of withdrawal of FTFs due to their death or capture, among the recent waves of voluntary abandonment (where presumably there have been hardly any place left for disoriented, repentant or regretful former FTFs) there should be more likely that they are found to be connected with the perpetration of serious violations of IHL and IHRL. Both the detection and the prosecution of possible FTFs raise a number of issues that, besides being multifaceted, have a considerable juridical component.

Repatriation is still a 'cross-cutting challenge'. To the initial reluctance from most governments, we must add the new political, legal, operational and security challenges which States continue to face due to Covid 19 (Eleventh report of the Secretary-General on the threat posed by ISIL to international peace and security, 2020, paras. 11 and 44).This scenario is also having negative impacts on the prosecution of those who have returned to their countries of nationality or habitual residence.

Although the issue regarding the prosecution of FTFs is mentioned in the UNSC Res. 2396 as well as in the Madrid Guiding Principles (including the Addition to them, made in

\footnotetext{
${ }^{57}$ See UN. Doc, S/RES/2379 (2017), para. 3.

${ }^{58}$ UNITAD Third report (November 2019), paras. 86-87.

${ }^{59}$ UNITAD Second report (May 2019), para. 50.

${ }^{60}$ Ibid.
} 
2018), it should be noted that as yet there is no universal strategy for ensuring the prosecution ofFTFs beyond acts related to terrorism, involving mandatory parameters at the international level (as those existing regarding criminalization of new conducts surrounding the creation of the category of FTFs or with respect to the financing of terrorism and the imposition of sanctions; either hard or soft law). Accordingly, a multi-agency framework to provide coordinated support to the requesting States on the protection, repatriation, prosecution, rehabilitation and reintegration of third country nationals returning from Iraq and Syria is been envisaged from the $\mathrm{UN}^{61}$. Therefore, the outcome of its future implementation remains to be seen. In any event, a coordinated strategy should be one of the primary focuses.

There are different policies concerning returnees, not only with respect to FTFs in general, but also as regards the specific treatment of women and children returning from or stuck in Iraq or Syria; between countries (thus, for example, the answers given by Canada, allowing return ${ }^{62}$; or France, not doing $\mathrm{so}^{63}$ ) and also between government officials or judiciary within the same country ${ }^{64}$.

It is clear that the number of prosecutions is disproportionately low compared to the total number of returnees ${ }^{65}$. Indeed, official figures show that only a minority of foreign jihadists has been prosecuted, since the States have been focusing their attention mainly on the threat of return. The existence of a problem to be managed in this sense must be recognized, which, in addition to its seriousness and complexity, is extremely delicate, since the scenario could still worsen ${ }^{66}$. However understandable these fears, it cannot be ignored that the response must always be determined by the requirements of international law. Even though this order is a largely relativistic one, it continues to offer clear legal guidelines. Besides, IHL offers opportunities which should be taken advantage of by legal practitioners (Paulussen, Cuyckens and Fortin, 2019). However, due, on the one hand, to the fears of the threat of terrorism (albeit legitimate and well-founded) and, on the other hand, to the problems related to evidence, international atrocity crimes are being neglected

\footnotetext{
${ }^{61}$ See UN Analytical Support and Sanctions Monitoring Team, 2018, para. 47.

${ }^{62}$ See Shephard (2017) .

${ }^{63}$ See references to the E. Konigen case: AFP, 'French female ISIS militant should face trial in Syria', January 4, 2018. Available at https://english.alarabiya.net/en/News/middle-east/2018/01/04/Paris-Frenchfemale-ISIS-militant-should-face-trial-in-Syria-.html

${ }^{64}$ Thus for example, see regarding Belgium, on the one hand, W. Van Wilgenburg (2019); and, on the other hand, 'Belgian appeals court says government can't be forced to bring back ex-Islamic State Mothers or their children', The Washington Post, February 27, 2019. Available at https:/www.washingtonpost. com/world/europe/belgian-appeals-court-says-government-cant-be-forced-to-bring-back-ex-islamic-statemothers-or-their-children/2019/02/27/1f432524-3ad9-11e9-b10b-f05a22e75865_story.html. See also the analysis sponsored by Egmont, finding convergences in the approaches adopted by Germany, France and Belgium: T. Renard and R. Coolsaet (2018), pp. 41 ff.; and B. Van Ginkel and S. Minks (2018), pp. 55 ff.

${ }^{65}$ For a coinciding approach, see E. U. Ochab (2018, "Known Genocidaires”); (2019, “Attempts to Address the Issue" and "The Investigative Team").

${ }^{66}$ It is assumed in this sense that Member States expect ISIS's FTFs and other terrorists to show flexibility in moving between groups, which may reinforce other terrorist groups, such as Al-Qaida, or generate new combinations or brands; Eighth report of the Secretary-General on the threat posed by ISIL (Da'esh) to international peace and security and the range of United Nations efforts in support of Member States in countering the threat, UN Doc. S/2019/103 (2019), para. 11.
} 
in prosecutions. In fact, most of the sentences released to date in different EU countries have imposed penalties on FTFs for propaganda, indoctrination or recruitment of militants (i.e. mainly in connection with acts of a terrorist nature and in some cases specifically involving women), but not for war crimes or crimes against humanity (and fewer still for genocide) ${ }^{67}$.

Prosecution for international crimes must also be a priority. Nevertheless, it is obvious that a perception of public security, conceived in its purely internal and narrower scope, is prevailing so far. Most national governments and public opinion believe that the best option is that FTFs stay away. This securitization, which has been extended to States and even international organizations like the $\mathrm{EU}^{68}$, can lead to a decreased effectiveness of the fight against terrorism in the medium and long term ${ }^{69}$. Counter-terrorist law is developing so rapidly that it also presents risks and problems (Bilková, 2018). One of these worrisome aspects is the ease with which it can cease to be intertwined in its application with IHL and IHRL. These are all branches of international law to which States (and International Organizations) must also abide when implementing UNSC resolutions.

\subsection{Gaps, Inconsistencies and Tensions between UNSC Resolutions}

UNSC resolutions 2379 and 2396 present a variety of deficits and inconsistencies. Both leave aside fundamental obligations related to the exercise of criminal jurisdiction by States. In the case of Resolution 2379 (without going into the serious gap resulting from the exclusion of crimes committed by actors other than ISIS), an opportunity has been wasted to refer to the principles of extraterritorial jurisdiction commonly associated with international crimes (the prosecution of which, however, was supposedly intended). Although the establishment of the Iraqi Investigative Team represents an important step towards holding ISIS members accountable, it should be kept in mind that this mechanism was primarily intended to collect, preserve and store evidence. It is striking that Resolution 2379 introduces a territoriality principle for third States, with an eye mainly on potential crimes that may be committed in the future (providing the opportunity that another Member State in whose territory Daesh 'has committed acts that may amount to war crimes, crimes against humanity, or genocide' may also 'request the Team to collect evidence of such acts' $)^{70}$. Therefore, it can be considered ironic and objectionable that jurisdiction for third States regarding potential or future crimes is envisaged (although it has been drawn on territorial support) while the current, necessary ways to take advantage of existing jurisdictional links with respect to atrocity crimes already committed have not been paved.

\footnotetext{
${ }^{67}$ See, for instance, the Spanish Audiencia Nacional's website. Available at https://www.poderjudicial.es/ cgpj/es/Poder-Judicial/Audiencia-Nacional/

${ }^{68}$ In this regard, experts have drawn attention to how even democratic systems have introduced"extraordinary legal means in supposedly 'ordinary law', giving credence to the criticism that the EU has opted for a sort of a permanent state of emergency hardly compatible with its founding value of the rule of law that is translated in to the EU legal system through general principles of law” (Martín Rodríguez, 2019, pp. 143-144).

${ }^{69}$ For warnings in this sense, see, among others, Ni Aoláin (2017 and 2018).

${ }^{70}$ Para. 11. Approval of the UNSC is needed for such use, though.
} 
In view of the above, Resolution 2379 should be considered a missed opportunity to incorporate the principles of nationality and universal jurisdiction as the exercise of these principles must be considered mandatory in the case of atrocity crimes and the Investigative Team must promote throughout the world accountability for atrocity crimes. Besides, both principles have enormous practical potential with regard to FTFs. Although it is indisputable that the crimes to which that Resolution refers were committed in Iraq, and that it is there where most evidence can be found, precisely limiting the mission of the Investigative Team exclusively to atrocity crimes (thus omitting not only the crimes recently typified by Resolution 2178 in relation to terrorism, but also other possible connected crimes $^{71}$ ) would also call for the incorporation of the principles of criminal jurisdiction in accordance with such a nature given that international crimes and extraterritorial principles of jurisdiction are essentially connected. Furthermore, the seriousness of the crimes needs to be kept in mind in line with the peremptory nature of the norms which are violated through their commission (norms which have a reinforced status beyond their condition of general International law, at the universal level, as they are norms of ius cogens). Consequently, Resolution 2379 also misses the inclusion of the most extraterritorial principle of all, that is, that of universal jurisdiction. However, it is true that the above argument is derived from an approach that only takes legal foundations into account, and not the political motivations behind the adoption of Resolution 2379. It is well known that political will, in the end, is always particularly hovering over both any decision regarding universal jurisdiction and any resolution which may be adopted in the UNSC framework.

It should be borne in mind that if the principles of extraterritorial jurisdiction were introduced, the content of the Resolution would be more coherent as the international crimes covered by it would be associated with the bases of jurisdiction that correspond to them by reason of their nature. In this regard, it also seems pertinent to emphasize the fact that leaving the matter to what the Iraqi Government may decide at any given moment is an option that is not in keeping with the international nature of the crimes at stake. In addition, it should be noted that nothing ensures that the Iraqi Government's future answers will always have to be positive ${ }^{72}$.

Along with the above, it is also possible to detect certain inconsistencies between the obligations derived from the main UNSC Resolutions seen thus far. Firstly, it can be missed that Resolution 2396 does not take advantage of its interrelation with Resolution 2379 to extract possible consequences and refer to consolidated rules of International law which rely on the heart of the matter concerned. Both resolutions were adopted in 2017, within the space of three months, on December 21 and in September, respectively, Resolution 2396 simply referring to the previous resolution in its preamble. Resolution 2396 (on the Iraqi Investigative Team) could have corrected the course initiated by Resolution 2178 (2014) in certain aspects which had already been examined (and which

\footnotetext{
${ }^{71}$ It should be borne in mind that certain acts of terrorism may constitute both war crimes and crimes against humanity, and in that sense they remain covered by Resolution 2379 and, in that sense, also included in the work of the Iraqi Investigative Team.

${ }^{72}$ There are precedents that show how frustrating the denial of legal aid can be in cases as serious as genocide, even in cases where the alleged perpetrators are not covered by any type of immunity; see Rwanda v. Nteziryayo and others. (2017) and also Ochab (2018, 'Known Genocidaires').
} 
created the misleading concept of FTFs) and recalled consolidated norms relevant to its application. Thus, the UNSC could and should have gone further in collecting possible available measures related to prosecution, since there is a vast content of international legal obligations regarding them, unlike what happens with respect to those related to rehabilitation and reintegration. Furthermore, this approach would have been preferable to prevent possible cases of impunity. However, the UNSC prioritized a fundamentally preventive conception, emphasizing the need to address the threat represented by returnees, particularly in terms of the prospect of future terrorist attacks, but ignoring, instead, a returnees' likely or possible connection with war crimes, genocide and crimes against humanity ${ }^{73}$. In this sense, the Resolution does not recall the existing state's obligations to tackle atrocity crimes, including, among others, duties of investigation and cooperation, some of which emanate from the Geneva Conventions and the international customary law. It should be remembered that in the case of serious breaches of the Geneva Conventions, the obligation of States to submit the case to their competent authorities for prosecution purposes, in accordance with the principle of universal jurisdiction (or, alternatively, to extradite to another jurisdiction in which sufficient charges have been charged) is not even restricted to cases in which the defendant is present in the territory of the State itself.

The atmosphere prevailing internationally concerning FTFs seems to be, therefore, a limited one, focusing on the threat posed by their return (Abad Castelos, 2019). An accompanying strategic plan regarding the prosecution of atrocity crimes would undoubtedly provide greater coherence among these recent UNSC resolutions between each other as well as with other obliged parameters to be taken into account ${ }^{74}$. Indeed, one of the challenges regarding international criminal law for the coming years is to redefine a solid theoretical framework on its purposes, which are sometimes not clear, due to its decentralized construction, even advancing through leaps, especially in certain historical moments (Olásolo and Galain, 2018, pp. 46, 51 and 139). Therefore, it is important to note that the fundamental normative criteria with respect to the atrocity crimes are clear. Besides, it is necessary to keep in mind that the obligations regarding the prosecution of crimes of genocide, against humanity and war crimes continue to exist, and the fact that the UNSC has been placing terrorism over crimes of atrocity in some resolutions never entails that these crimes may not be prosecuted as such.

\footnotetext{
${ }^{73}$ See paras. $21-41$.

${ }^{74}$ These are undoubtedly significant in this regard. Thus, UNSC resolutions 2249 and 2253 reaffirm that 'those responsible for committing or otherwise responsible for terrorist acts, violations of international humanitarian law or violations or abuses of human rights must be held accountable'. Likewise, in another resolution adopted in 2018, the UNSC refers to, among other goals, 'promot(ing) accountability and the protection of human rights, and judicial and legal reform, in order to strengthen the rule of law in Iraq, in addition to supporting the work of the investigative team established in resolution 2379 (2017)'; UN Doc. S/RES/2421(2018), para. 2 d).
} 


\section{Second Approach to Unitad: Its Key Role to Overcome Serious Obstacles in the Field of Criminal Justice Regarding the Foreign Terrorist Fighters}

\subsection{The background regarding Justice: An inextricable Labyrinth}

It would be ideal if an international court, such as the ICC, could take charge of prosecuting these crimes. Yet, for varied reasons, the ways to achieve this are currently unworkable: Iraq, the country where the crimes have been committed, has not even ratified the Rome Statute; nor does a referral by the UNSC seem foreseeable either; furthermore, in 2015 the Prosecutor denied the possibility of resorting to the principle of nationality by not using the link between the FTFs and their home States which are States Parties to the Rome Statute ${ }^{75}$.

Most of the trials for the crimes perpetrated in Iraq are taking place in that country, including cases involving FTFs. This situation presents major shortcomings and deficits. To begin with, there is no lack of paradox given that the Iraqi courts are prosecuting the alleged perpetrators of mass atrocities when their courts do not even have jurisdiction over war crimes, crimes against humanity or genocide. Therefore, far from applying the criminal rates corresponding to these international crimes, they are simply applying the criminal types connected with terrorist offences, where certain behaviors which occurred do not fit as they should (such as, and this is only a sample, the serious acts of sexual violence committed by Daesh as a war tactic). It is true that a reform of the Iraqi Criminal Code is being prepared in order to introduce international crimes (UNAMI/OHCHR, 2020 , p.2), but by the time such international crimes are finally operational and applied by the Courts, thousands of trials will already have been held. Thus, NGOs and media started warning about that condition of these trials do not meet the minimum standards for a fair trial. There have been prosecutions without even credible identifications of those accused (Human Rights Watch. 2017, 2020) ${ }^{76}$ and without the necessary guarantees for the different stages of a trial, some being held in just ten minutes, according to various reports ${ }^{77}$. Neither have minimum standards been met for the application of the death penalty, once it has been imposed. Taking all these reasons into account, a number of official bodies affirmed the duty of third States to repatriate or request the extradition of their FTFs to prosecute them before national courts (Report by the Special Rapporteur on extrajudicial, summary or arbitrary executions on her mission to Iraq, 2018).

\footnotetext{
75 The ICC Prosecutor considered that ISIS is an organization led primarily by Iraqi and Syrian nationals (Syria is not party to the Rome Statute either), in such a way that the FTFs would presumably not be among those most responsible for the serious crimes committed: ICC, Statement of the Prosecutor of the International Criminal Court, F. Bensouda, on the alleged crimes committed by ISIS (8 April 2015). Available at https://www.icc-cpi.int/Pages/item.aspx?name=otp-stat-08-04-2015-1. This decision has been the target of justified criticism; see Zakerhossein (2016), pp. $613 \mathrm{ff}$.

${ }^{76}$ HRW has also shown cases in which informants (whose identity was kept secret) proposed the inclusion of certain names due to unresolved disputes of a personal, family, tribal or territorial nature.

${ }^{77}$ See Klausen (2019).
} 
The United Nations Assistance Mission for Iraq, through its Human Rights Office, and the Office of the United Nations High Commissioner for Human Rights have published a report in 2020 showing that from January 2018 to October 2019, Iraqi tribunals processed over 20.000 terrorism-related cases, with thousands pending at the beginning of 2020 (UNAMI/OHCHR, 2020, p. iv). In any event, this report covers the period from May 2018 to October 2019, after monitoring 794 criminal court hearings in different Iraqi cities ${ }^{78}$. UNAMI human rights officers monitored 794 hearings in criminal courts, attending hearings on a regular random basis. The majority of them (619 hearings; i.e., 78\%) concerned defendants prosecuted under anti-terrorism laws and were used as the basis for the analysis and findings presented. These 619 terrorism-related hearings included 28 cases involving foreign defendants from 11 different countries of origin. UNAMI findings show serious concerns that fair trial standards were not respected, in particular: violations of fair trial standards relating to equality before the courts; the overreliance on confessions, with frequent allegations of torture and ill-treatment inappropriately addressed by courts; prosecutions under the anti-terrorism legal framework (with a vague definition of terrorism and related offences) focused on "association" with or "membership" of a terrorist organization, "without sufficiently distinguishing between those who participated in violence an those who joined ISIL for survival and/or through coercion, and with harsh penalties that failed to distinguish degrees of underlying culpability"; the imposition of the death penalty after unfair trials; practical restrictions on the publicity of hearings, lack of victim attendance in proceedings and overreliance on a charge of "membership" of a terrorist organization. Of the 317 terrorism-related trial hearings in federal courts attended by UNAMI officers, which involved the pronouncement of sentences, judges decided the death penalty in 100 instances, which implied the $31,5 \%$. Setting aside other possible criteria which can also render subsequent executions arbitrary, it is relevant to keep in mind that the lack of respect of the rights to consular assistance of foreign nationals is one of them.

Although there is an agreement between UNAMI and the Supreme Judicial Council of Iraq (2020) to jointly develop guidelines for the conduct of trials according with international human rights standards ${ }^{79}$, and many of the serious breaches shown are essentially related to the functioning of the courts, a significant part of them actually escape their control, since they have to do with the lack of a proper normative framework and deficiencies in the design of the anti-terrorist policy, among other factors. These concerns refer, therefore, to multilevel and complex problems, which, in any case, must be solved, at least if one hopes to eliminate possible motives for reviving conflict in the country. The very title of the report mentioned above, written by UNAMI and OHCHR, is highly illustrative: Human Rights in the Administration of Justice in Iraq: Trials under the antiterrorism laws and implications for justice, accountability and social cohesion in the aftermath of ISIL. Precisely, among its conclusions it is worth mentioning the emphasis placed on "the root causes of violence and conflict in Iraq" which "need to be addressed in terms of human rights violations suffered by all communities in the country over several

\footnotetext{
${ }^{78}$ Anbar, Baghdad, Basra, Dhi-Qar, Dohuk, Erbil, Kirkuk, Ninewa, and Wassit governorates.

${ }^{79}$ See Eleventh report of the Secretary-General on the threat posed by ISIL to international peace and security (August 2020), para. 50.
} 
decades. This includes adherence to crucial elements of robust safeguards for detention, procedural guarantees and fair trials. This would demonstrate commitment to justice, while also constituting a necessary building block towards greater inter-community reconciliation and social cohesion" (UNAMI/OHCHR, 2020, p. 14).

\subsection{UNITAD's work may bring new significant tools to deal with the FTF's prosecution for atrocity crimes beyond terrorist offences}

UNITAD has diversified its lines of investigation focusing on new issues in relation to crimes committed beyond those attacking Yazidis and Christians. Thus, on the one hand, it has also drawn up extensive lines of enquiry concerning the crimes committed against the Kaka'i, Shabak and Shia Turkmen communities, as seen before, and on the other hand, it has opened other specialized thematic units related with the sexual and genderbased crimes and crimes against children. Therefore, although the most advanced briefs currently being prepared by the Team are still connected with the crimes against Yazidi community (started in Sinjar in August 2014) and the mass killing of unarmed Iraqi air force cadets and military personnel from Tikrit Air Academy (in June of the same year), which should be both finalized by June 2021, the other remaining initiatives are also being prioritized and will be vital to address grievances and resentment that could be conducive to terrorist recruitment. In March 2020, the religious leaders of the Christian, Kakai, Shiite, Sunni and Yazidi communities adopted an Interfaith statement on the victims of ISIS, emphasizing the strong collective repudiation of its ideology by all religious communities and highlighting the need for concerted action to hold ISIS members accountable for their crimes in accordance with the rule of law, based on the work of UNITAD. In coherence with that, the Special Adviser and Head of the Investigative Team at the time, Karim Asad Ahmad Khan, has always been stressing, that the Team will ensure that "there is no hierarchy of victim" in its approach to the implementation of its mandate ${ }^{80}$.

Furthermore, UNITAD has made tremendous progress on all three major fronts of research activities related to its core function, i.e., collection and storage of evidentiary material. Thus, with respect to the documentary, testimonial and digital evidence collection, its achievements may be added to the general advances made in this area, as specifically those related to electronic media, including digital evidence obtained from open sources ${ }^{81}$, and the collection of evidence by new actors in scenarios of armed conflict, which will bring novelties for any potential domestic proceeding. In fact, the Investigative Team has initiated in April 2020 a major technical assistance project in strengthening the capacity of Iraqi authorities, in order to comprehensively map and digitize documentary, digital and other material relating to crimes committed by ISIS. This information will be incorporated into its evidence base ${ }^{82}$. Also very recently, the cooperation with the Iraqi security services has enabled the extraction and analysis of data from mobile phones, SIM cards and mass

\footnotetext{
${ }^{80}$ See, for instance, his Brief to the UNSC on his Fifth Report Security Council Open VTC. Available at http://webtv.un.org/watch/investigative-team-to-promote-accountability-for-crimes-committed-by-da $\%$ E2\%80\%99eshisil-unitad-security-council-open-vtc/6215533377001/?term=.

${ }^{81}$ See Freeman (2020), pp. 48-67.

${ }^{82}$ See UNITAD Fourth report (May 2020), para 66.
} 
storage devices previously used by ISIS members, which has 'the potential to shift the paradigm' for their prosecution, in Iraq and globally ${ }^{83}$. It will allow, for instance, that FTFs may be geolocated retroactively, determining their whereabouts at the time of the alleged commission of international crimes. Concerning the excavation of mass graves, UNITAD has conducted a comprehensive review of priorities in cooperation with the Iraqi Government and the International Commission on Missing Persons, leading to the adoption of a common mass graves excavation strategy in $2020^{84}$. Dealing with the storage, analysis and management of evidence, the Investigative Team has also achieved new progress in collaboration with the United Nations International Computing Centre and the Microsoft Corporation Tech for Social Impact and Artificial Intelligence for Humanitarian Action Initiative ${ }^{85}$.

Since UNITAD was established in September 2017, has issued five successive reports (being the first one from 2018). A chronological reading of these documents is eloquent enough, in particular since the Team began to work on the ground. Even despite the time lost by the Covid-19, and the consequent stoppage of trips and operations, the innovative approach that it has managed to introduce in the implementation of its mandate, has led to a significant and meritorious evolution. Thus, in synthesis, it is worth noting its vision and strategic action, in continuous progress, which has allowed it to add new crucial lines of research, as we have already seen, and more specifically, to develop the following pillars of action currently underway, which are "mutually supportive":

"(a) thematic and overarching case briefs corresponding to the key investigative priorities of the Team that describe, explain and analyse evidence collected, and offer a legal characterization of offences disclosed by that evidence;

(b) individual case files in relation to particular suspects identified by the Team as being responsible for those crimes; and

(c) the targeted delivery of support in response to requests from domestic authorities" "86.

Through the coordinated implementation of these three pillars, UNITAD seeks "to maximize the relevance of its work to ongoing domestic proceedings and establish a clear framework for the allocation of resources through to the completion of its mandate" 87.

Firstly, the case briefs are crucial to build a bridge between the terrorism-related offences and the atrocity crimes as UNITAD will address, for instance, the existence of a requisite as of a widespread and systematic attack against a civil population in the case of crimes against humanity. Therefore, this step represents a key to alleviate the existing gap between, on the one hand, the crimes related to terrorism that the Security Council focused on when confronting the phenomenon of foreign terrorist fighters, particularly in its

\footnotetext{
${ }^{83}$ Ibid., para 108.

${ }^{84}$ See UNITAD Fifth report (November 2020), para 56.

${ }^{85}$ See ibid., para 67.

${ }^{86}$ Ibid., para 21.

${ }^{87}$ Ibid.
} 
resolution 2178 (2014) and, on the other hand, war crimes, against humanity and genocide, which constitute the leitmotif of UNITAD's work. Consequently, UNITAD's work can be crucial to bridge the gap and smooth out inconsistencies highlighted on previous pages.

Secondly, in addition, the Team goes even further, addressing the production of case briefs addressing the contextual basis of crimes under investigation. In this work, it has come to develop a wide range of individual case files "detailing the evidence linking specific members of ISIL to the crimes described in those briefs". UNITAD is focusing its efforts on those "most responsible for the crimes committed" by ISIS in accordance with its mandate, "including regional or mid-level commanders and those responsible for the ordering and commission of such acts" "88. Also, the Team has recently reached an agreement with the Iraqi Supreme Judicial Council to support the joint development of case files with Iraqi investigative judges, in anticipation of the future legal basis in Iraq for the prosecution of crimes committed by ISIS as war crimes, crimes against humanity and genocide ${ }^{89}$. This seems quite significant since there are still foreign fighters in Iraqi custody.

Thirdly, it is necessary to keep in mind the ability and willingness of UNITAD to give a targeted support responding to requests for assistance in ongoing prosecutions against foreign fighters. It is precisely in relation to this third point where the greatest potential of UNITAD with respect to foreign terrorist fighters can be displayed, insofar it will be able to respond to requests made by other third national authorities, other than Iraqis. In fact, eight European countries where legal proceedings are being carried out against ISIS members for international crimes have asked the Team for help to date. In response, it has strengthened the forms of assistance which is able to provide, including: "cross-checking evidence held by domestic authorities against the evidence holdings of the Team; identifying and interviewing witnesses and survivors who are capable of providing accounts relevant to ongoing investigations by domestic authorities; and pursuing the targeted collection of evidence relevant to such proceedings, in consultation with domestic authorities" $"$

However, to exercise jurisdiction by third countries, obstacles of various kinds need to be overcome, starting by those related to the repatriation of FTFs in the case of the principle of nationality ${ }^{91}$. Indeed, there are new opportunities in matter of evidence, as we have seen above, but reluctance from third States still prevails. In addition, the path of universal jurisdiction will continue to be open (and the innovations regarding evidence might also be welcome here), although even greater resistance from governments must be overcome. Despite a certain upturn can be observed thanks to the positive action of countries such as Germany, Sweden or Finland, precisely in relation to crimes committed in Syria and Iraq (Trial International, Universal Jurisdiction Annual Review, 2020), there

\footnotetext{
${ }^{88}$ Ibid., para 30.

${ }^{89}$ According to the schedule anticipated by UNITAD, the first case files produced under such arrangement will be completed in the second half of 2021; see ibid, para 33.

${ }^{90}$ Ibid., para 36.

${ }^{91}$ As it has been said, "the term foreign fighters perpetuates the notion that foreign fighters are not part of our society, but nothing can be further away from the truth. These foreign fighters are foreigners in Iraq and Syria, but they are our own citizens' (Mehra and Paulussen, 2019).
} 
is no indication of substantial change so far, at least implying a new systematic use. In any case, Finland is one of the (eight) States that is using this hotline with UNITAD, as revealed in its latest reports (although there are no references with respect to the other States which are also involved). Along this line the Investigative Team keeps striving to promote accountability globally for acts that may constitute atrocity crimes, while protecting the interests of survivors, as it is stated in its mandate.

Taking all the above into account, it is necessary to highlight that the existence of two different track approaches to prosecution, i.e., terrorism and atrocity crimes at the international level, should not be a problem as such in practical terms, due to the fact that both ways are compatible between each other and even complementary. Thus, UNITAD can help to overcome the insufficiencies of a prevalent focus on terrorism at the international level, allowing national authorities to go beyond the offences merely linked with terrorism. Its mission can be vital as what it gathers evidence not only collected by itself, but also by other actors, both those who have been working in the field (such as the armed forces or NGOs) and who are able to provide any valuable data (due to the experience of any negative effect, being victims or witnesses, or through any other kind of access), ensuring that the database of evidences is as complete as possible with respect to the crimes committed by ISIS in Iraq. Furthermore, the fact that UNITAD's work is focused on atrocity crimes allows national jurisdictions to be the beneficiaries of an enormous potential. In fact, in the absence of UNITAD, it would be impossible, or at least very difficult, that most of the evidence obtained could reach national jurisdictions, including the Iraqi one, which is, after all, its first recipient. Therefore, it is necessary to contribute to the dissemination of UNITAD's work in the judicial spheres of third States. This task is necessary not only in the States in which territory there are FTFs (mostly, of their nationality or with residence there), but also beyond, precisely because of the natural connection of the atrocity crimes that must be prosecuted with the principle of universal jurisdiction.

\section{Conclusions}

While, on the one hand, UNSC Resolution 2379 creates the Iraqi Investigative Team, in order to collect, preserve and store evidence on the atrocity crimes committed there, on the other hand, the obligations derived from UNSC Resolutions 2178 and 2396 focus on FTFs and terrorism-related crimes, neglect the strategy for accountability for the most serious crimes. In particular, a specific discrepancy is observed, especially between Resolution 2379 and 2396. Despite the fact that both were adopted almost at the same time, and having to a certain extent the same object (the latter provides measures related to the prosecution of returnees, among others), it is regrettable that their contents are actually disconnected.

By focusing attention on the FTFs from a primarily anti-terrorist perspective, the UNSC neglects the articulation of means to make their responsibility effective for atrocity crimes. Furthermore, this contributes to the confinement of agendas (both national and international) within security aspects, at the cost of other equally necessary dimensions. 
Indeed, the aforementioned discordances and tensions tend to exacerbate the problems of the antiterrorist sector of International law, by deepening the ongoing securitization process.

Furthermore, those inconsistencies contribute to the political entanglement in which the situation is trapped regarding many FTFs. There are no magic formulas to ensure prosecution, not even of alleged perpetrators of crimes as heinous as the genocide against certain communities. We must be aware that geopolitical balance together with national interests will prevent a possible transit along certain paths. Political will is essential for everything at the international level, even for issues where a priori it seems to go unnoticed.

Inconsistencies such as those detected in the legal sphere should be corrected in order to avoid further possible inconsistencies between the objectives of International law, since this order pursues two parallel fights, on the one side, against terrorism, and, on the other, against impunity for atrocity crimes. Notwithstanding, overcoming such inconsistencies seems an especially difficult task since these problems do not arise from carelessness (which could be remedied as soon as the alarm sounds), but rather from an intense obstinacy impregnating a number of strategies which deal with terrorism. For this reason, a quiet reflection is required not only about such causes, but also about other broader issues with which they are connected, because, in the end, the greater issue here is to meditate on the future that we all want for society. The society which embraces all and is for all as we live together in an global space where political borders are in many ways accessories or even irrelevant. Consequently, although not all of us want the same, those who use legal tools will have to remain alert to detect possible violations and contradictions on a daily basis, as well as to explore optimal paths and convergence points to stick to in the fight both against terrorism and against impunity for serious international crimes. Synergies need to be enhanced.

In addition, another idea needs to be introduced that goes beyond the legal sphere. It is perhaps obvious, but it often seems to be ignored or undervalued in political decisions made in reality. There is a need to take into account that the factors that gave rise to the emergence of ISIS (and to the armed conflicts originated to confront it) have yet to be resolved. They are still there. Consequently, despite the military defeat of the ISIS' political-administrative infrastructure in Iraq and Syria, fertile ground remains for its resurgence. To which other equally disturbing elements must be added: the lack of an adequate transitional justice in Iraq; the growing social and political instability which Iraq is experiencing; the fact that a considerable number of FTFs are not detained, as well as the presence of more weapons in the region than ever before; and the depletion of all kinds of human and financial resources destined to combat terrorism due to the Covid-19 pandemic at the same time that ISIS could start to bounce back in Iraq and Syria. This vicious circle leads us to a scenario of nightmare proportions.

As long as the inconsistencies detected continue, national political authorities should carry an extra burden on their shoulders, being more focused on repatriation efforts of nationals and ensuring possible avenues for future prosecutions on the basis of national and universal jurisdiction. For that, it is necessary, and possible to take advantage, on the one hand, of the global condemnation of ISIS, and, on the other hand, of the UNITAD's strategic and valuable task. 
Despite the fact that UNITAD was born weighed down by serious limits (such as its restricted mandate, ISIS crimes-related only, and its subordination to the Iraqi Government), the impeccable and diligent exercise of its mission is allowing to overcome certain obstacles and strengthen a path that could, and should, be used by third States in relation to foreign terrorist fighters, both through the jurisdictional principles of nationality and universality. Although there are enormous challenges ahead, the progress in gathering evidence on different planes and the Team's action to promote worldwide accountability are so far meritorious and solid. Now the ball is also in the court of third States: through their governments (to repatriate FTFs, or even to extradite them) or / and their tribunals (to exercise jurisdiction) in relation to atrocity crimes, and not just with regard to offences of terrorism. An already existing bridge should be used, since UNITAD is able to provide valuable evidence and tools which may be central in prosecuting FTFs in third countries. Indeed, the capitalisation of UNITAD's work, taking advantage of its data, knowledge and fruits by jurisdictions of third States, could help to eliminate, or at least to soften, the gap between the two tracks referring FTFs: one related to prosecution of terrorism crimes and another connected with atrocity crimes. Harnessing this potential could therefore contribute greatly to raising the level of the track related to the prosecution of atrocity crimes to the place it deserves in practice (and not only in the theory of International law). But for this it is necessary that UNITAD's work be more widely disseminated and well received in domestic frameworks, particularly in the judicial domain. Justice needs to be promoted because there can be no peace without justice and it is a plausible way to plant seeds that could generate a virtuous future cycle for the protection of human rights and social cohesion, in Iraq and beyond, thus preventing further conflicts.

\section{REFERENCES}

ABAD CASTELOS, M. (2019), ¿Es posible combatir el terrorismo yihadista a través de la justicia? El retorno de los combatientes del Estado islámico tras sus crímenes, Barcelona: J.M. Bosch. https://doi.org/10.2307/j.ctvq2w4jh

AMBOS, K. (2014), “'Our Terrorists, Your Terrorists? The UNSC Urges States to Combat 'Foreign Terrorist Fighters'”, but Does not Define 'Terrorism', EJIL: Talk!, 2 October 2014. Available at https://www.ejiltalk.org/our-terrorists-your-terroriststhe-united-nations-security-council-urges-states-to-combat-foreign-terroristfighters-but-does-not-define-terrorism/

BILKOVÁ, V. (2018), "Foreign Terrorist Fighters and International Law", Groningen Journal of International Law, Vol. 6, Number 1, pp. 1-23. https://doi. org/10.21827/5b51d51a22ac3

CLOONEY, A. (2017), 'Finally, We Have a Coordinated Effort to Bring ISIS to Justice', The Huffpost, September 22, 2017. Available at https://www.huffingtonpost.com/ entry/amal-clooney-isis_us_59c569bae4b01cc57ff22947?guccounter=1).

DE KERCHOVE, G. (2016), 'Foreword', in Foreign Fighters under International Law and Beyond, A. De Guttry, A. Capone, F. and C. Paulussen (eds.), Springer / Asser Press: The Hague. 
FREEMAN, L. (2020), 'Prosecuting Atrocity Crimes with Open Source Evidence: Lessons from the International Criminal Court', in Digital Witness. Using Open Source Information for Human Rights Investigation, Documentation and Accountability, Oxford University Press, pp. 48-67.

FUKUYAMA, F. (2018), Identity: The Demand for Dignity and the Politics of Resentment, London: Profile Books.

GILMORE, S.A. (2018), 'Introductory Note to United Nations Security Council Resolution 2379', The American Society of International Law. https://doi.org/10.1017/ ilm.2018.41

\section{HUMAN RIGHTS WATCH:}

- (2017), Flawed Justice. Accountability for ISIS Crimes in Iraq, December 5, 2017. Available at https://www.hrw.org/report/2017/12/05/flawed-justice/ accountability-isis-crimes-iraq\#

- (2020), How to Answer Iraq's Dangerous Failure to Put a Stop to Torture (written by B. WILLE), Available at https://www.hrw.org/news/2020/09/16/ how-answer-iraqs-dangerous-failure-put-stop-torture

ICC (2015), Statement of the Prosecutor of the International Criminal Court, Fatou Bensouda, on the Alleged Crimes Committed by ISIS (8 April 2015). Available at https://www.icc-cpi.int/Pages/item.aspx?name=otp-stat-08-04-2015-1.

ICRC (2015), 32nd International Conference of the Red Cross and Red Crescent, Doc. EN32ic/15/11 (December 2015).

KLAUSEN, J. (2019), 'Jihadists Head Home Thousands of Westerns Joined ISIS. Should They Be Allowed to Return', Foreign Affairs, June 6, 2019. Available at https:// www.foreignaffairs.com/articles/europe/2019-06-06/jihadists-head-home

MALET, D. (2018), 'The European Experience with Foreign Fighters and Returnees', in Returnees: Who Are They, Why Are they (not) Coming Back and How Should We Deal with Them? Assessing Policies on Returning Foreign Terrorist Fighters in Belgium, Germany and the Netherlands, T. Renard and R. Coolsaet (eds.), Egmont Paper 101 (February 2018).

MARRERO ROCHA, I. (2019), 'The European Union's Foreign 'Terrorist' Fighters', in Jihadism, Foreign Fighters and Radicalization in the EU. Legal, Functional and PsychosocialResponses, I.MarreroRochaandH.M. TrujilloMendoza(eds.),London and New York: Routledge, pp. 44-63. https://doi.org/10.4324/9780429468506-4

MARTÍN RODRÍGUEZ, P. (2019), 'The Rule of Law and the Fight against Terrorism and Radicalization in the European Union', in Jihadism, Foreign Fighters and Radicalization in the EU. Legal, Functional and Psychosocial Responses, I. Marrero Rocha and H. M. Trujillo Mendoza (eds.), London and New York: Routledge. https://doi.org/10.4324/9780429468506-8 
MATAR, J. (2019), The War Report. Iraq: Any Hope for Change?, The Geneva Academy (November 2019), at 2. Available at https://www.geneva-academy.ch/joomlatoolsfiles/docman-files/Iraq\%20Any\%20Hope\%20for\%20Change.pdf

MEHRA, T., and PAULUSSEN, C. (2019), 'The Repatriation of Foreign Fighters and Their Families: Options, Obligations, Morality and Long-Term Thinking', International Centre for Counter-Terrorism, The Hague, March 6, 2019. Available at https:// icct.nl/publication/the-repatriation-of-foreign-fighters-and-their-families-optionsobligations-morality-and-long-term-thinking/

NI AOLÁIN, F. (2017), Letter of the UN Special Rapporteur on the Promotion and Protection of Human Rights while Countering Terrorism, September 22, 2017.

NI AOLÁIN, F. (2018), 'The UN Security Council, Global Watch Lists, Biometrics, and the Threat to the Rule of Law', 17 Just Security, January. Available at https:// www.justsecurity.org/51075/security-council-global-watch-lists-biometrics/

OCHAB, E.U. (2018), 'Known Genocidaires and Daesh Foreign Fighters Avoid Prosecutions in the UK', Forbes, April 27, 2018. Available at https://www.forbes. com/sites/ewelinaochab/2018/04/27/known-genocidaires-and-daesh-foreignfighters-avoid-prosecutions-in-the-uk/\#1 e5e16ca76cf

OCHAB, E.U. (2019), 'Attempts to Address the Issue of Foreign Terrorist Fighters Continue', Forbes, February 22, 2019. Available at https://www.forbes.com/ sites/ewelinaochab/2019/02/22/attempts-to-address-the-issue-of-foreign-fighterscontinue/\#4727f7641cd2.

OLÁSOlO, H., and GALAIN PALERMO, P. (2018), Los desafios del Derecho internacional penal, Tirant: Valencia.

OSCE and UNOCT (2020), "OSCE and UNOCT discuss ways to responsibly use passenger data to prevent return of foreign terrorist fighters". Press release, October 30, 2020. Available at https://www.un.org/counterterrorism/sites/www.un.org. counterterrorism/files/20202030_press_release_comprehensive_input_comms. pdf

PAULUSSEN, C., CUYCKENS, H., and FORTIN, K. (2019), 'The Prosecution of Foreign Fighters under International Humanitarian Law: Misconceptions and Opportunities', International Centre for Counter-Terrorism, The Hague, December 13, 2019. Available at https://icct.nl/publication/the-prosecution-of-foreign-fightersunder-international-humanitarian-law-misconceptions-and-opportunities/

RENARD, T., and COOLSAET, R. (2018), 'From the Kingdom to the Caliphate and Back: Returnees in Belgium', in Returnees: Who Are They, Why Are They (not) Coming Back and How Should We Deal with Them? Assessing Policies on Returning Foreign Terrorist Fighters in Belgium, Germany and the Netherlands, T. Renard and R. Coolsaet (eds.), Egmont Paper 101 (February 2018), pp. 19 ff..

SAUL, H. (2016), 'Amal Clooney Delivers Damning Speech to the UN Over Failure to Stop ISIS 'Genocide": 'I am Ashamed”, The Independent, September 17, 2016. Available at https://www.independent.co.uk/news/people/amal-clooney-delivers- 
damning-speech-to-the-un-over-isis-genocide-i-wish-i-could-say-im-proud-tobe-a7313551.html.

SEGURA SERRANO, A., (2019), "National Measures Implementing United Nations Resolutions on Foreign Fighters", in Jihadism, Foreign Fighters and Radicalization in the EU. Legal, Functional and Psychosocial Responses, Marrero Rocha, I. and Trujillo Mendoza, H.M., (eds.), London and New York: Routledge, pp. 148166. https://doi.org/10.4324/9780429468506-9

SHEPHARD, M. (2017), '22-year-old Montreal Woman Escapes Daesh with Infant Daughters Three Years after Travelling to Syria', November 27, 2017. Available at https://www.thestar.com/news/world/2017/11/27/22-year-old-montreal-womanescapes-daesh-with-infant-daughters-three-years-after-travelling-to-syria.html

SMITH, A. (2014), 'Iraqi Vice-president on Sunni Oppression, Nouri Al-Maliki and Sectarian Division ', Middle East Monitor, 28 August 2014. Available at https://www. middleeastmonitor.com/20140828-iraqi-vice-president-on-sunni-oppressionnouri-al-maliki-and-sectarian-division/

\section{SOUFAN GROUP:}

- (2014) Foreign Fighters in Syria.

- (2015) Foreign Fighters; An Updated Assessment of the Flow of Foreign Fighters into Syria and Iraq.

- (2017) Beyond the Caliphate: Foreign Fighters and the Threat of Returnees.

TRIAL INTERNATIONAL, Universal Jurisdiction Annual Review, 2020. Available at https://trialinternational.org/wp-content/uploads/2020/03/TRIAL-International_ UJAR-2020_DIGITAL.pdf

UK, Royal Courts of Justice, Government of Rwanda v. Nteziryayo and others. Available at https://www.judiciary.uk/judgments/rwanda-v-nteziryayo-and-others/

UN ANALYTICAL SUPPORT AND SANCTIONS MONITORING TEAM SUBMITTED PURSUANT TO RESOLUTION 2368 (2017) CONCERNING ISIL (DA'ESH), AL-QAIDA AND ASSOCIATED INDIVIDUALS AND ENTITIES:

- (2017), Twenty-first report, Doc. S/2018/14/Rev.1. https://doi.org/10.1002/ mmr.31019

- (2018), Twenty-second report, Doc. S/2018/705.

\section{UNAMI/OHCHR:}

- (2014), Report on the Death Penalty in Iraq Baghdad. Available at https://www. ohchr.org/Documents/Countries/IQ/UNAMI_HRO_DP_1Oct2014.pdf

- (2017), Report on the Protection of Civilians in the Context of the Ninewa Operations and the Retaking of Mosul City, 17 October 2016 - 10 July 2017; 
November 2017. Available at http://www.uniraq.org/images/factsheets_reports/ Mosul_report\%2017Oct2016-10Jul201731\%20October_2017.pdf

- (2018), 'Unearthing Atrocities: Mass Graves in Territory Formerly Controlled by ISIL', 6 November 2018, p. 16, para. 9. Available at https://www.ohchr.org/ Documents/Countries/IQ/UNAMI_Report_on_Mass_Graves4Nov2018_EN.pdf

- (2020), Human Rights in the Administration of Justice in Iraq: Trials under the Antiterrorism Laws and Implications for Justice, Accountability and Social Cohesion in the Aftermath of ISIL. Available at UNAMIS's website: https:// www.uniraq.org/index.php?option $=$ com_k2\&view $=$ itemlist\&layout $=$ category\&task $=$ category $\& \mathrm{id}=164 \&$ Itemid $=650 \overline{0}$ lang $=$ en.

\section{UN GENERAL ASSEMBLY}

Resolution (2016), Doc. A/RES/71/248.

\section{UN HUMAN RIGHTS COUNCIL}

- (2011), Doc. A/HRC/S-171.

- (2015), Doc. A/HRC/S-24.

- (2017), Doc. A/HRC/36/31.

- (2018), Doc. A/HRC/38/44/Add.1.

- (2018), Doc. A/HRC/39/L.22.

UNITED NATIONS INVESTIGATIVE TEAM TO PROMOTE ACCOUNTABILITY FOR CRIMES COMMITTED BY DA'ESH/ISLAMIC STATE IN IRAQ AND THE LEVANT (UNITAD)

- (2018) Terms of Reference of the Investigative Team to Support Domestic Efforts to Hold ISIL (Da'esh) Accountable of Acts that May Amount to War Crimes ÿ Crimes against Humanity and Genocide Committed in Iraq, established pursuant to Security Council resolution 2379.

- (November 2018), First Report of the Special Adviser and Head of the UNITAD, Doc. S/2018/1031.

- (May 2019), Second Report of the Special Adviser and Head of the UNITAD; Doc. S/2019/407.

- (November 2019), Third Report of the Special Adviser and Head of the UNITAD, Doc. S/2019/878.

- (May 2020), Fourth Report of the Special Adviser and Head of the UNITAD; Doc. S/2020/386.

- (November 2020), Fifth Report of the Special Adviser and Head of the UNITAD, Doc. S/2020/1107.

\section{UN SECRETARY GENERAL:}


- (2019), Eighth Report of the Secretary-General on the Threat Posed by ISIL (Da'esh) to International Peace and Security and the Range of United Nations Efforts in Support of Member States in Countering the Threat, Doc. S/2019/103.

- (2020), Eleventh Report of the Secretary-General on the Threat Posed by ISIL (Da'esh) to International Peace and Security and the Range of United Nations Efforts in Support of Member States in Countering the Threat, Doc. S/2020/774.

UN SECURITY COUNCIL, Letter dated 14 August 2017 from the Chargé d'affaires a.i. of the Permanent Mission of Iraq to the United Nations addressed to the President of the Security Council, S/2017/710.

UN SECURITY COUNCIL, Resolutions:

- (2001), Doc. S/RES/1373.

- (2014), Doc. S/RES/2170.

- (2014), Doc. S/RES/2178.

- (2017), Doc. S/RES/2379.

- (2017), Doc. S/RES/2396.

- (2018), Doc. S/RES/2421.

UN SECURITY COUNCIL, Counter-Terrorism Committee (2015), Guiding Principles on Foreign Terrorist Fighters, Doc. S/2015/939.

UN SECURITY COUNCIL, Counter-Terrorism Committee (2018), Addendum to the Guiding Principles on Foreign Terrorist Fighters, Doc. S/2018/1177.

UN SPECIAL RAPPORTEUR ON EXTRAJUDICIAL, SUMMARY OR ARBITRARY EXECUTIONS:

- (2017), 'End of Visit Statement of the Special Rapporteur on Extrajudicial, Summary or Arbitrary Executions on Her Visit to Iraq', Baghdad, Iraq, 24 November 2017. Available at https://www.ohchr.org/EN/NewsEvents/Pages/ DisplayNews.aspx?NewsID $=22452 \&$ LangID $=\mathrm{E}$

- (2018), Report on Her Mission to Iraq, UN. Doc. A/HRC/38/44/Add.1.

UN SPECIALRAPPORTEUR ON THE HUMAN RIGHTS OF INTERNALLY DISPLACED PERSONS (2020), Report on its Visit to Iraq, A/HRC/44/41/Add.1 (2020), par. 70.

VAN GINKEL, B., and MINKS, S. (2018), 'Addressing the Challenge of Returnees: Threat Perceptions, Policies and Practices in the Netherlands', in Returnees: Who Are They, Why Are They (not) Coming Back and How Should We Deal with Them? Assessing Policies on Returning Foreign Terrorist Fighters in Belgium, Germany and the Netherlands, T. Renard and R. Coolsaet (eds.), Egmont Paper 101 (February 2018), pp. $55 \mathrm{ff}$. 
VAN SCHAACK, B. (2018), 'The Iraq Investigative Team and Prospects, for Justice for the Yazidi Genocide', 16 Journal of International Criminal Justice. Available at https://papers.ssrn.com/sol3/papers.cfm?abstract_id=3099932 https://doi. org/10.2139/ssrn.3099932

VAN SCHAACK, B. (2018), 'UN Releases Guidelines for Team Investigating ISIS Crimes in Iraq. Death Penalty Debate Dodged', February 19, 2018, Just Security. Available at https://www.justsecurity.org/52628/iraqi-investigative-team-termsreference-released-death-penalty-debate-dodged/

VAN WILGENBURG, W. (2019), 'Judge: Belgium Should Return IS-children Immediately', Kurdistan 24, December 26, 2018. Available at http://www. kurdistan24.net/en/news/1654bb2d-679d-439b-94c6-7122faff4456

ZAKERHOSSEIN, M.H. (2016), 'To Bury a Situation Alive - A Critical Reading of the ICC Prosecutor's Statement on the ISIS Situation', International Criminal Law Review, Vol. 16, pp. 613 ff. https://doi.org/10.1163/15718123-01604007

Received: $28^{\text {th }}$ January 2021

Accepted: $21^{\text {st }}$ April 2021

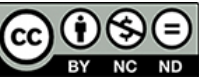

